\title{
Journalism in the Age of Digital Technology
}

\section{Vineet Kaul, DAIICT University, India}

\begin{abstract}
The information age has created many challenges for every profession. In the case of journalism the introduction of information technology has altered considerably various aspects of the profession. The high tech revolution has significantly altered the way the public obtains its news and information, and has deprived the mass media of its traditional monopoly. This paper will explore intersections between new media, journalism and technology in order to enhance our understanding of the influence of information and communication technology, specially internet technology on traditional journalism. The media and the practice of journalism, however, have been slow to adjust to the Internet and the global ramifications produced by the new information technology. In the past decades, journalists in the Western World have benefited from the tremendous growth in information communication technologies - ICTs - and in the last ten years the ICTs have also penetrated the developing world and have made available computers, Internet access, and mobile technology. This development has probably eased journalistic working procedures in these parts of the world. Though journalists throughout the world still separate "domestic" from "foreign," while their audiences casually chat between continents.
\end{abstract}

Today various computerized sources are regularly being used in media organizations. This paper investigates the adoption of information technology, three broad themes reflecting the role of the media in the digital age emerged from the Journalism, how journalists use these new tools to advance their profession, write for global audience and news gathering, the role of Internet; what the security and ethical implications are in this new realm; and whether freedom of the press necessarily means freedom of access, confusion created by new digital technologies and the power, speed and usefulness of digital creation, transmission and reception.

This paper also considers that while the new digital platforms and technologies do present significant challenges to traditional journalism, they are also enabling technologies that offer 
opportunities to reinvigorate newsgathering. Although the future of journalism is a digital one, the core competencies of a good journalist will be as important as ever.

Keywords: journalism, digital technologies, information technology, traditional monopoly, media, production of news, computer and internet access

\section{Introduction}

In today's fast-paced society, more and more people are turning to their computers, cell phones, and Bluetooth devices for updates ranging from Facebook to weather predictions. Especially with the explosion of social networking and the development of smart phones, technology is quickly becoming the primary way of receiving information. New technological dependence for information does have benefits- instant notifications of news and emails allows society members to be aware of what is going on in the world in only a few seconds. With communication being an important part of any culture, the way in which information is spread has to adapt to fit the way people live. Journalism was once largely print based when the majority of people wanted to take time to read newspapers. Now as people are turning to the internet for their information needs, print journalism is slowly being cast aside and some even consider print journalism a dying art, as shown by the steady decline of print newspaper sales. Journalism departments all over the world have to rethink the way journalism is being taught, as techniques of fifteen years ago are not applicable today. The journalism landscape is constantly changing, with new technologies and mediums re-defining the relationship between the news media and the public.Human nature being what it is, some people fear change while others eagerly embrace it. Some are excited by the opportunity to profit from changing circumstances. Others are inclined to follow the rule of the "dangerous precedent," which states that absolutely nothing should ever be done for the first time. In today's world, however, it is impossible for anyone to escape the relentless process of change. This is especially true for those working in journalism and communications.

The god term of Journalism- the be-all and end all, the term without which the enterprise fails to make sense, encompasses all facets of society and human understanding since the beginning of civilization. Newspapers have been the major media of journalistic materials from the era of pigeons to Wi-Fi internet.Unlike the incremental developments of the past, 
today's telecommunications revolution marks a fundamental change of direction. We are faced with the challenge, and the opportunity, of doing things in an entirely different way. New technology is reshaping the most fundamental aspects of our communications system, and we are now forced to reconsider our most basic assumptions about how that system will be used to gather and to distribute the news. This Article will offer a brief glimpse of the shape of things to come, followed by some difficult, and still unanswered, questions that should concern anyone who cares about journalism and its impact on society.

\section{Technology and Journalism Practices}

Over the past quarter century, dramatic technological advances in the production, manipulation, and dissemination of images have transformed the practices of journalism, entertainment, and advertising as well as the visual environment itself. In an age of ubiquitous information news junkies have never had it so good, at the touch of a button, online news is available everywhere from the "Times of India" on the web to online versions of the "The Hindustan Times" daily. With massive changes in the media environment and its technologies, interrogating the nature of news journalism is one of the most urgent tasks we face in defining the public interest today. The implications are serious, not just for the future of the news, but also for the practice of democracy. The essential notion is that journalism traditionally has been very effective at shining a spotlight on the problems and developments of the day. But, traditional journalism, for a variety of reasons, has often failed to place those stories in enough contexts to understanding them fully. One of the most significant reasons has been technological. Moreover, the traditional, analog media have been largely one-way in their information flow, from the journalist to the public. This passive audience model has limited the involvement or engagement of the public in journalism and public affairs.

The arrival of the digital revolution - the evolution of the Internet, the emergence of new forms of media, and the rise of online social networks - has reshaped the media landscape and made "the press" of 2011 something that many could not have imagined. From digital retouching to wholesale deception, the media world is now beset by an unprecedented range of professional challenges. Not only because of the different media that arise, but the new dynamics of work. Every day the new devices and tools are added in exponential growth that sometimes appears to cause an excess of choices and opportunities that journalists and audience don't know yet. These new frontiers of media have enriched news and information 
resources and reshaped what has traditionally been the realm of print press, broadcasters, and news agencies. The challenge is to optimize fully the potential of the Internet and digital media without compromising civil liberties.

Digital technologies have charted revolutionary changes in journalism and fundamentally altered the nature and function of media in our society, reinventing age-old practices of public communication and at times circumventing traditional media and challenging its privileged role as gatekeepers of news and entertainment. There are myriad ways in which digital technologies have impacted on the practice of journalism, from the way reporters gather information and present news stories to how news organizations structure themselves and do business.Digital technologies have expanded quickly, permeating society with new formats and possibilities of communication. Hypertext, multimedia, hypermedia have become part of the routine of the vast majority of professionals and require schools to change their ways of teaching and learning. If we peer into the future, we can foresee a media landscape dominated by a highly fragmented, though active audience, intense media competition, and scarce advertising dollars. By embracing new technologies, professional journalism and media can hold on to their role as a vital information lifeline and continue to operate as the tool of a successful democracy.

With the dawn of the information age (and electronic journalism), journalists' functions have shifted from information transmission to information processing (Jurgensen \& Meyer, 1992; Schudson, 1995). In McLuhan's works, we learn that every medium presents a different sensory experience to extend the self into the world. It comes as no surprise then that journalism's foundation has begun to change with the latest medium - the Internet. The unique Internet attributes of interactivity and multimedia are forcing significant evolutions in journalistic culture as the basic mission of the reporter has evolved for the digital world. Web technology has provided opportunities for sources and audiences to participate in news production. Scholars have begun calling reporters "gatewatchers" (Bruns, 2005) and information "monitors" (Deuze, 2003), insisting that they share authority willingly and embrace "citizen media" (Gillmor, 2004). Buzz words such as "networked journalism" (Jarvis, 2006) and "communal media" (Jenkins, 2006) demonstrate how some people are thinking about the Web technology as an opportunity for a journalistic revolution (Bruns \& Jacobs, 2006) where citizens have a responsibility to speak up, create content, and counter 
mainstream media in virtual venues (Kline \& Burnstein, 2005). This largely theoretical essay puts forth a new online model for news production functionality that takes into account the dynamics of information production, dissemination and consumption online.

The world communicates 24/7 without deadlines or geographical barriers. The reader decides what, when and how to read, in addition to having a voice through low-cost digital publications, free of government interference. The digital revolution in information and communication technologies has created the platform for a free flow of information, ideas and knowledge across the globe and myriad ways in which changes and challenges are brought to the purveyors and the consumers of the news. We assume that the journalist is not an endangered species, but one whose functions and routines are being altered drastically. Now a website can operate as a platform upon which citizens may voice their opinions and questions regarding the issues about which they care" (Deuze, 2003, p.218). And, "dialogic" journalism is a more liberating notion of news creation: "The content of a new medium is fully maintained by journalists interacting with citizens" (219). The audience member (or the receiver) is taking an active role in journalism. At their core, these new models suggest profound changes for journalists' roles and their ultimate control over the news. Digital technology demands more of the reporter, who often has to learn several operating functions, working at the same time as producer, editor and executor. All those functions used to be distributed among various sectors.

Apart from a plethora of content available for dissemination, new technology also makes it possible for patterns of similar events and issues to be associated across various societies. Solutions to local problems are no longer restricted to the community themselves but are picked up by interest groups, the world over and projected as exemplars. Newspapers throughout the world that have invested in other media are beginning to experience both the advantages and difficulties of a convergence whose catalyst is the Internet and whose immediate future will be the total integration of their news and commercial multimedia operations. As technologies became much more complex, the task of investigating, producing and disseminating news increased not only the skills required of a reporter, but also the speed of publication in the frenetic pace of writing instantaneously and 24/7. Media industry veterans may find the tech-driven changes unfamiliar and uncomfortable at first, but they would do well to embrace the inevitable. We could say that with digitization, the journalist 
finally became a specialist, not in anything in particular, but in effective ways to perform journalism and make the newspaper quickly and widely available.

The era of mass media is giving way to one of personal and participatory media. That will profoundly change both the media industry and society as a whole."(The Economist, 2006, p.3) The Age of Participation goes beyond the so-called Era of the Internet and requires a new way of thinking about the worldwide network of computers, whose initial structure did not anticipate and does not involve the user on a large scale. Classical theories of mass communications are being reworked for the new media, because of its structural differences. The new media has also removed passivity among the media audience by enabling simultaneous reception, alteration and redistribution of cultural objects. It dislocates communicative action from the posts of the nations, provides instantaneous global contact and inserts the late modern subject into a machine apparatus that is networked. Marshal McLuhan had first associated technology with content in his celebrated treatise. He outlined four different media cultures. The first was the ancient culture of oral communication, exemplified by many of the old Sanskrit texts followed by a literature culture using the phonetic alphabet and a handwritten script which coexisted with the oral culture. The third progression, according to McLuhan described as 'The Gutenberg Galaxy' was that of massproduced mechanical printing. Finally we are in the midst of what is known as the culture of the 'electric media' — radio, television and computers.

But as we have seen earlier, computer mediated communication provides a separate media culture altogether. The important characteristics of the new media are that media texts are dematerialized in the sense that they are separated from their physical — newsprint — form. The data can be compressed into very small spaces and it can be accessed at very high speeds in non-linear ways.

The explosion in new media forms has grabbed the attention of communication scholars in the latter half of the 1990s. The number of studies is burgeoning, and new ones appear at a steadily accelerating pace (Singer, 1998). This new revolution is marked by neologisms. "Blog" became part of the Webster dictionary in 2004, the New Oxford American Dictionary adopted "podcast" in 2005. "Wikis", "Vlogs", "metaverse" and "folksonomies" may be next. They all relate to phenomena that occur in cyberspace with the user in the role of the leading 
man. The focus has been primarily on the audience for computer-based media forms, particularly on the uses and effects of these new media (Lievrouw and Livingstone, 2002; Garrison, 1998; Garrison, 2000). With the boost of users looking for information in new places, the mass media industry, in general, seems to have moved to keep their audience's attention by increasingly going online to offer news and information. The audience seems divided between a segment who want headlines and useful information bits and a fraction who want in-depth data documents and in-context reports (Kenney, et al., 2000). Another qualitative aspect is the unique possibility of the Internet to supply links to story sources (Deuze, 1998).

The concept-requiring people to pay for digitally distributed news-sparks broad debate over how journalism might be funded, what journalism means and should mean, who qualifies as a journalist, and journalism's role. Journalism is a public good, but who will pay for it in the future? In the past, media markets in many countries have had both private and public funding. The big media houses, generally run by private companies, are the outlets that offer general international and national news, but these are the very ones facing economic pressures from the rise of digital media. Today, targeted niche markets, such as science, business, and sports, often deliver the profits that media owners seek - as do sensationalist, populist, and biased news. What are the new business models going forward? The use of the Internet as a major information source raises important questions on the future funding of media, on the need for journalists' unions to examine their strategies for organizing new work forces in journalism, and on ways to create new partnerships with citizens to defend press freedom. It is no secret that journalism is undergoing a shift: "We don't own the media anymore," said the director of the BBC World Service and Global News division back in 2005. Media owners and managers face great challenges adjusting to the new digital world: to continue to fund newsrooms staffed by professional journalists or to rely on blogs and other user-generated content. One of the challenges includes continuity of funding of investigative journalism which has been traditionally supported by well-established media companies. Will this approach be affected by increased reliance on individual digital media users? Are there possible alternative funding models in addition to advertising, subscriptions, and donations? How to ensure that journalism remains independent of political and commercial interference and influence in the face of changing revenue models? 
Finding the balance between generating profits in a new business environment-while holding on to well-established journalistic standards and maintaining editorial independence - has emerged as one of the most pressing and urgent issues for journalism in the digital age.

Media as an institution is shocked by its weakened authority and influence, victimized by the desecration of information and is lost in the digital noise. It's faced with a revolution on all fronts: the upheaval of information production, distribution, and consumption. It appears like professional journalism is attacked on all sides - and seems less necessary and useful. However, yet the solution to the "information overload" that overwhelms us daily is journalism! Bear in mind the answer is a new form of journalism - an "augmented journalism," enriched with new possibilities of the digital age. Journalism with added value, which mainly exists on digital platforms but can be transferred to others as well. The transformational crisis will sweep away those do not have any added value services to offer the public. Now as a digital reporter ( not print reporter,) you have to go out and sometimes you need to shoot pictures, you need to shoot video, you need to get the story and you need to ask the right questions. But you have to get it on some sort of digital recording device as well and you have to bring that back into the office and process it. So to be a journalist in the digital age, you have to be able to be an editor, a photographer, a videographer, a reporter, a layout designer and a writer all in one. Those who do survive will offer individuals and communities a better way to understand and participate in civic life, along with enrichment and simplification of people lives.

Journalism in the digital age faces one overwhelming fact - a shortage of human digits to input all those ones and zeros, a crisis that threatens global discourse over every other crisis a headline writer might care to sub. All around the world, new fangled data journalists are number crunching furiously, except in their own backyard. Without wanting to advocate for a new breed of "journo-geek," let's be thankful for the emergence of the plethora of opportunities. The digital narrative allows us to better comprehend world events (global warming, migration issues, the economic crisis) through graphics, enrichment of experts and victims' testimonies, conversations taking place over various locations, and collaboration with other media. These multiple interconnections and broad guidelines render the process more proactive. Data journalism permits for visual information to be transformed into 
knowledge, and knowledge constitutes an enormous developmental potential. This does not even include the imminent changes from "augmented reality" and how that will enrich information.

Journalism can rise again. Its power will be less about the production of specific information; rather it will filter the tsunami of the world's information. There will be more emphasis in sorting, selecting, editing, aggregating, and linking elements between events, ideas, and people. Those at the top will provide the best information at the right time to those who need it. We are betting there will be an augmented journalism that is more transparent and humble in its practices, business, investigation, sources, connections, etc.

To accomplish this feat, journalism will have to reinvent itself. Everybody fumbles, but its not longer time to question whether to let the train pass us by or just put one foot out the door. It's time for innovation for transformation. It's not "adapt or die," rather "change or die." For a while traditional media was reluctant in confronting the digital age. Yet the public and advertisers, often more technologically sophisticated, will simply go elsewhere.

There is hope to continue to be a key vehicle for serious news, because journalists are more equipped to effectively collect, sort, converse, and link with a range of innovative tools. There is also hope in fighting the tyranny of choice and information overload on the web, which threatens to result in an attention crash. There is hope in the continuous enrichment of information through editorial content and technology.

It's a good period of time for journalists who are, as writer Erik Orsenna says, "In the business of being vigilant during a time when the world is changing." It's good time for journalists because there has never been so much of an appetite for information! The digital age is an exciting time for revolutionary journalists and editors.

Journalists can not be spectators in this current revolution, where the biggest enemies are themselves. They can not ignore the earthquake that is changing the landscape. They can not barricade themselves away from the global conversation and rest upon a pedestal that no longer exists. 
Like others, journalists reacted slowly but it's clear they must reinvent their role. If not, then new users will decide what content is pertinent. What is really the alternative?

Contextualized Journalism

Do digital media and traditional news media have competing or mutually complementary relationships? What is needed for an enabling environment for synergy between the two? How will journalists in traditional print and broadcast media use new tools in their reporting and in distribution of news content? The answer is that the new media present an opportunity to transform the situation by enabling reporters to do five things differently with their stories. First, stories can make connections. They can do this through hypermedia, or links, the connecting tissue fundamental to the World Wide Web, the global publishing medium of the Internet. Through links, reporters can provide additional background or depth to their stories. This is especially important for stories that have long lives, or that run for many days, weeks or months, even years. Many times, readers may forget or simply be unaware of the history of a story, some of the names or terms that are mentioned. Reporters in traditional media don't always have space or time to explain all this background in every story, but through links, they can point to the relevant material.

Second, new media can be interactive. Audience members can interact with each other or with reporters or sources, engaging in a dialog. Rather than sit back and only watch or listen, audience members can participate in a discussion room on line. They can send email to a reporter. The reporter may get an important lead on a story. A factual error might be quickly corrected. Audiences can interact with content. They can navigate through a 360-degree video. They can click on a "hot spot" and access additional information, text, audio or video that further explains a story element.

Third, new media permit a wider or richer use of communication modalities. Words, spoken or written, background sound, still photographs and graphics, motion pictures, and more are all possible in a digital, networked environment. All of these modalities give the reporter more tools to tell a story and can engage audiences more fully by engaging more of the audience members' senses. Research shows that attention, understanding and retention are all increased when more communication modalities are engaged in the classroom. There's no reason why the same can't be true in journalism. 
Fourth, content can be more dynamic in a digital environment. It can be updated and kept current in an online medium such as the Internet or digital broadcasting system. Moreover, content is available on-demand and flows continuously from source to receiver and back again. This fluid system keeps the audience and journalist in a constant state of connection, whether the audience or journalist is at home, newsroom, or out and about in their community connected through a mobile phone, two-way pager or wireless personal digital assistant.

Finally, new media make possible a new level of customization never possible before in journalism. Journalists have always strived to make their stories relevant. When stories break on a national, regional or even international stage, good journalists have always tried to localize them. They have always tried to find a local connection, a person, place or consequence for the home town, state or country. But, new media make it possible to take this journalistic ideal of localization to the ultimate level of the individual. Every story can be potentially made relevant to each individual person. This is impossible in traditional media.

\section{Themes Reflecting the Role of the Media in the Digital Age}

Trepidation, confusion and celebration are three broad themes reflecting the role of the media in the digital age. The sense of trepidation relates to a fear of the unknown and unknowable: a sense that digital technologies are changing at a speed that confounds attempts to master them before they morph into new forms. This fear is somewhat justified by tracing the feedback loop that has developed between YouTube and the mainstream media. The rapid dissemination, interpretation and reconfiguration of the story demonstrate a real challenge to traditional newsgathering.

Another confusion created by the new digital technologies is related to the fetish-isation of gadgets and the growing gap between users who have always interacted with the digital world and those who have had it thrust upon them. The terms 'the golden age of gadgets' and 'the third age of gadgets', posited that the 'harbinger of this change was the iPod' and a new economy was developing around consumer electronics. This was driven by competition between large computer and electronics companies (Zjawinski, 2003). The cultural status of devices like the iPod and ubiquity of feature-packed mobile phones and other devices generates confusion about their utility (Mollgaard, 2006). While these gadgets are indeed 
remarkable for their storage capability, multimedia abilities and communication powers, they are in themselves neutral technologies. They require users and content to operate.

There is also confusion about the fundamental differences in the experiences of the digital age of those born before and after 1980. Named the 'digital immigrants' and the 'digital natives' these two groups are portrayed as living on opposite sides of a chasm of skills and experience in the digital age (Prensky, 2001). This gap in digital competencies relates to the vastly different media and communication experiences these two groups have grown up with. The advent and development of the microchip, the internet and the digital economy have meant a change in the traditional allocation of power between young and old and a shift in values and practices in business, education and entertainment.

The third theme was cautious celebration. The power, speed and usefulness of digital creation, transmission and reception open up communication and the media to people in previously unimaginable ways. The creator/consumer audiences that are evident in the new public arenas of YouTube, Blogspot and MySpace indicate that people want to participate in and share their media and information experiences.

These are the three main motivations that are driving these 'virtual communities': anticipated reciprocity (the sharing of content), increased recognition (peer esteem) and a sense of efficacy (the achievement felt when creating complex digital content) (Kollock, 1999). These motivations are shaping the content that media organisations produce in that there is increasing recognition that meeting their audiences in the middle ground of cyberspace requires content that is media-rich, targeted carefully and allows user participation in the experience by being able to pass it on to others of their ilk and also contribute their own content.

\section{Learning New Media Tools}

During 20th century journalism was regarded largely as a trade. Barriers to entry were low typically just a high school degree was required - and so newsrooms regularly had a healthy influx of young blood. 
Then j- schools - many of them staffed with theoreticians and academics rather than real reporters - mush-roomed across the country. Journalism became a middle-class job, then a profession. The pay got better. Newspapers, especially large metro dailies, started taking themselves very seriously. No longer could a talented kid just out of college or even one with a few years experience land a job at a paper in New Delhi or Mumbai. Then from 1990s and 2000s, newsrooms were increasingly dominated by baby boomers at or approaching middle age. Not surprisingly the tone and content of those papers reflected that mindset, from the news sections to the arts and entertainment pages. If music critics raised on the Beatles and the Rolling Stones struggled to keep up with grunge and hip hop, is it any wonder the news business has been so slow to respond to the Internet revolution going on around it?

The digital technology has changed the equation and "News providers throughout the rich world are urgently casting around for new models," according to a report by the Economist. There is a new world out there, a market driven by highly literate, technology savvy and endlessly searching for new tech consumers. The digital age has barely begun and newspapers are finding ways to adjust. . Besides, newspapers are still searching for business and editorial models that are sustainable in this new world of media. The introduction of new media technologies in the newsroom has led to a disintegration of distinct and specialist skills. Instead, the new emphasis is on the "multi-skilling" of journalists. That is, within the newsroom sphere, journalists are now expected to be able to be able to write, edit, present and sometimes film and produce their work in order for their story to make it into the newsroom. Sparks (1991) argues that this multi-skilling of journalists leads to the labour exploitation, as well as detracting the core of journalism away from journalistic principles and practices. Ursell argues that the expectation placed on journalists to be able to perform in such various ways leads to the deskilling of others within the journalistic field, as well as a decrease in exceptional news content and stories.

This has caused many j-schools and media industries insiders to ponder the future of journalism's amid frequent changes. The salt-flats speed of technology haunts the syllabi of new media journalism professors. Yet for all the time new technologies gobble up, the primary challenge for journalism schools in 2011 is a more basic question of identity: What should a journalism program teach in the digital world? For much of the 20th century, journalism schools had a bit of vocational school in their DNA. Unlike a philosophy 
professor - who, let's face it, doesn't expect his or her students to pay their mortgage on Sartre's shoulders - a journalism professor could reasonably expect that good students could build careers in journalism. Still, most journalism schools haven't seen any dip in applications, and in fact many graduate programs have grown. Where will all those graduates work? Is that even the right question for journalism schools anymore, considering the wider value of the skills journalism programs teach?

It's easy to see the negative in the media. Hysteria is loud. It's true that the cable news networks are disasters of disinformation, that some bloggers nibble at a shrinking buffet of other people's reporting, and that some newspapers are so broke they're outsourcing reporting to India. But that sulfuric smell obscures what's blooming. When I tell my costudents that this is an incredible era to be a journalist, it's not delusional. Will young people suddenly become avid news consumers when the digital transformation is complete? The evidence suggests not. And while solving journalism's logistical problems seems tough but doable, discovering how to capture the attention of a generation that cares little for news in any form is another matter entirely.

Media educators cannot remain indifferent to the increasingly significant role that digital media devices play in the education system. This is all the more important given the significance of the issue. When observing the manner in which teachers use such media, there is a fear of a regression in terms of the critical reflection at stake in the use of digital media. The audience wants information. Giving voice to the voiceless has never been easier: find the truth, and tell people about it.

\section{The Twenty-First Century Electronic Journalist}

Thanks to an abundance of bandwidth, the model for electronic journalism in the digital domain will be the on-line database, rather than the daily newspaper or regularly scheduled television news program. The primary vehicle for news distribution will be a self-defining, open network, rather than traditional point-to-multipoint broadcasting or print. The twentyfirst century news machine will be an interactive, multimedia system possessing the power of television, the portability of newspapers, and the flexibility of the telephone network. It will take maximum advantage of an open network that makes much more efficient use of available bandwidth than a one-way, closed system like broadcasting or cable television. 
Consumers will be able to participate in the news process. Journalism will become less of a lecture and more of a conversation. Journalists will spend less time guessing what their customers might want to know and more time packaging and organizing an almost infinite body of raw material into reliable and useful information packages.

More separate news organizations will appear, each a good deal smaller and more specialized than those we see today. From these smaller and more efficient news operations, a far greater volume and variety of news will emerge, aimed at much smaller audiences than today's news departments. The very notion of "mass" media will fade into history. Before long, the hot news format will be individually customized "information on demand." News gathering and production equipment will continue to get cheaper and easier to use. The news gathering and presentation process that once required a large staff of technical specialists will be performed quite routinely by lone reporters armed with inexpensive camcorders, notebook computers, and portable telephones. The material these newspersons produce will be simultaneously created and distributed in a wide variety of formats. To survive in this more demanding and competitive environment, news producers will have to find new ways to profit from smaller shares of the total audience.

\section{The Future of New Technology}

When you're finished changing, you're finished." - Benjamin Franklin.

Old Benjamin had it spot on - and it's proven throughout the history of journalism. Imagine if the journalists of old had not gone from the trusty town crier and ventured into the modern, and unknown, world of print. Many, many years later we introduced radio and later was the jump to television.

When you think about it, these were big, big changes. They all faced massive challenges, and I'm sure massive failures -just look at News 24. But now they are the staples of our media landscape, and trusted information delivery systems.

We now face a new challenge - the deep dark hole of the Internet. Vast, unexplored and seemingly infinite. There are people, journalists, who would rather stay in the safe confines of their trusty, unchanging landscape but as with all development, eventually it will arrive on 
your doorstep. If it knocks politely or barges in with force depends on how acquainted you have become with it. Unfortunately this applies to all types of change.

People are calling this change Journalism 2.0, but it should really be up to version $10+$ by now. To call it a new version is to say it's superseding something outdated that may not be totally true. Television did not replace radio, even though they both use sound as a medium. Pod-casting has not replaced live radio. So why should the Internet or citizen journalism be the replacement of them all.

To push your skills to their boundaries and learn something new, to seek out cross media publication at a range of outlets - to train yourself. It's not unloyal, it's not disrespectful and it certainly doesn't put your integrity in doubt. After all, we are all students, and we are here to learn as much as we can while we have the chance.

To finish up I say "Change is inevitable. Progress is optional."

\section{Conclusion}

The real danger is not from monopolistic corporations setting up tollbooths on the electronic superhighway, or from digital pirates hijacking intellectual property. It is from wellintentioned public officials who try to protect outdated, incumbent technologies and seek to regulate content. New technology soon will provide the power to turn billions of digital bits into unlimited amounts of useful information available to all. But this new power will create the awesome responsibility to preserve every citizen's freedom of access to that information and the right of everyone to participate in the continuing digital conversation. Traditional journalistic practices developed in an age of scarce distribution. But, journalistic values are not dependent on scarcity, and they need not be compromised by abundance. The value of storytelling will not diminish merely because there is greater access to the underlying raw data. At the same time, however, it would be foolish to ignore the fact that if new technology encourages everyone to speak at the same time, nobody will be heard or understood.

The twenty-first century news machine will soon be a reality, bringing enormous benefits, even as it forces society to make difficult choices. Without a doubt, this new technology will change journalism. It is up to society to make sure that this change is for the better. If the free press and journalistic ethics are to survive the treacherous journey into cyberspace, society 
needs to answer the tough questions that new technology will raise about the role of journalism in a free society, remembering that technology, no matter how powerful, can only be as useful and worthwhile as human beings decide to make it. As Edward R. Murrow warned many years ago, technology without thoughtful human involvement is merely "lights and wires in a box." 


\section{References}

African Continent Population Estimate (n.d.). (Retrieved 5 February 2011): www.xist.org/earth/pop_region.aspx

BBC ( n.d.) : Haveyoursay. (Retrieved 5 February 2011) : http://news.bbc.co.uk/2/hi/talking_point/4784595.stm

Bolter J.D. and Grusin R. (2000). Remediation. Cambridge: The MIT Press.

Cameron, D. (2006). The rocket in your pocket: How mobile phones became the media by stealth. Paper presented at the Second Joint Journalism Education

(JEA)/Journalism Education Association of New Zealand (JEANZ) conference,Auckland, December 4-7.

Cavanagh, P. (2006). The future of radio in the digital age. Panel at the Second Joint Journalism Education (JEA)/Journalism Education Association of New Zealand

(JEANZ) conference, Auckland, December 4-7. Geohive Internet Access: Africa (2007). (Retrieved 5 February 2011): www.geohive.com/earth/ec_inet.aspx

Greenslade, R. (2006). Keynote address at the Second Joint Journalism Education(JEA)/Journalism Education Association of New Zealand (JEANZ) conference, Auckland, December 4-7.

Hirst, M. (2006). Broadcast to Narrowcast: how digital technology is reshaping the mass media. Paper presented at the Second Joint Journalism Education (JEA)/Journalism Education Association of New Zealand (JEANZ) conference, Auckland, December 4-7.

Hetherington, S. (2006). The virtual newsroom-using wiki technology to create alearning environment for student print journalists. Paper presented at the SecondJoint Journalism Education (JEA)/Journalism Education Association of New Zealand (JEANZ) conference, Auckland, December 4-7.

Hoar, P. and Hope, W. (2002). The internet, the public sphere and the 'digital divide' in New Zealand. Journal of International Communication. 8(2): pp.64-88. 18 PACIFIC JOURNALISM REVIEW 13 (1) 2007 JOURNALISM DOWNUNDER

Internet World Statistics (2007) . (Retrieved 5 February 2011) : www.internetworldstats.com/stats.htm 
Kollock, P. (1999) The economies of online cooperation: gifts and public goods in cyberspace. In Kollock, P and Smith, M. (Eds). Communities in Cyberspace (pp. 220-239). London: Routledge.

Mollgaard, M. (2006). Radio journalism in the age of podcasting. Paper presented the Second Joint Journalism Education (JEA)/Journalism Education Association of New Zealand (JEANZ) conference, Auckland, December 4-7.

Murphy, T. (2006). The future of newspapers in the digital age. Seminar at the Second Joint Journalism Education (JEA)/Journalism Education Association of New Zealand (JEANZ) conference, Auckland, December 4-7.

Murrell, C. (2006). Interactive student podcasting: the emerging technology ofchoice. Paper presented at the Second Joint Journalism Education (JEA)/Journalism Education Association of New Zealand (JEANZ) conference, Auckland,December 4-7.

Nathan, T. (2006). The future of television in the digital age. Seminar at the Second Joint Journalism Education (JEA)/Journalism Education Association of New Zealand (JEANZ) conference, Auckland, December 4-7.

Prensky, M. (2001). Digital natives, digital immigrants. On the Horizon 9(5): pp. 3-6.

The 11 layers of citizen journalism (2007). (Retrieved 5 Febuary 2007): www.poynter.org/content/content_view.asp?id=83126

Thorburn, D., and H. Jenkins (2003). Rethinking media change: the aesthetics of transition. Cambridge: The MIT Press.

Zjawinski, S (2003). The golden age of gadgets. Wired. (Retrieved 5 February 2007): www.wired.com/wired/archive/11.12/start.html?pg=2 